\title{
Comparison of methods available for assay of chloramphenicol in clinical specimens
}

\author{
J DE LOUVOIS, ANNE MULHALL, AND ROSAlinde HURLEY \\ From Queen Charlotte's Maternity Hospital and the Institute of Obstetrics and Gynaecology, \\ London, UK
}

SUMMARY Eight methods for the assay of chloramphenicol in clinical samples were compared with our own modification of a plate diffusion technique using Sarcina lutea and yeast extract agar. Six of the eight methods were less sensitive than originally reported, and five of them were considered unsuitable for use in clinical microbiology practice. The remaining three methods together with the $S$. lutea/yeast extract modification were used to assay chloramphenicol in 20 samples of serum. Twenty samples of cerebrospinal fluid were also assayed by the $S$. lutea/yeast extract method. Our results indicate that only the Bacillus subtilis (sensitivity $6.0 \mathrm{mg} / \mathrm{l}$ ) and the $S$. lutea (sensitivity 2.5 $\mathrm{mg} / \mathrm{l}$ ) diffusion methods are suitable for use with clinical samples in routine practice. The problems of chloramphenicol toxicity, appropriate dosage regimens, and the need for assay of the drugs are considered.

The liability of chloramphenicol to provoke toxic effects with fatal outcome ${ }^{12}$ limits its usefulness, and it is generally reserved for the treatment of some cases of typhoid fever or other serious Gram-negative infections, ${ }^{3}$ finding application in paediatric, neurological, and neurosurgical practice.

The toxic side effects are enumerated by Wade and Reynolds. ${ }^{4}$ While irreversible and sometimes fatal aplastic anaemia (incidence 1:20 000-1:80 000) appears to be idiosyncratic and is, perhaps, genetically determined, depression of the bone marrow and the gray syndrome in premature and other newborn infants are dose related. ${ }^{56}$ Reversible depression of the marrow occurs usually when plasma chloramphenicol concentrations reach $25-35 \mathrm{mg} / \mathrm{l}$, and the gray syndrome has been reported most frequently in infants given more than $50 \mathrm{mg} / \mathrm{kg}$ body weight daily. Reduced doses are advised for those with impaired renal or liver function, but there is little uniformity of view on appropriate dosage regimens for premature and other neonates. Recommendations taking account of prematurity have been made ${ }^{7-9}$ but it is unlikely that dosage schedules that are both therapeutic and relatively non-toxic can be determined unless plasma and tissue concentrations of the drug can be measured reliably and accurately for each individual.

Received for publication 3 December 1979
A number of methods for the assay of chloramphenicol have been described, with varying claims for their sensitivity, reliability, and accuracy. We have compared eight of them with our own modification of a diffusion method using a minimal medium and Sarcina lutea as indicator organism. This study has been undertaken as part of a wider investigation of the pharmacology of chloramphenicol in premature and immature neonates, the results of which will be reported later.

\section{Material and methods}

\section{CHLORAMPHENICOL STANDARDS}

Purified chloramphenicol powder (Parke Davis) was used to prepare standards in horse serum ( $\mathrm{pH} 6 \cdot 8)$ and phosphate buffered saline ( $\mathrm{pH} \mathrm{7.0)}$ in the range $2 \cdot 5-30 \cdot 0 \mathrm{mg} / \mathrm{l}$, stored at $-20^{\circ} \mathrm{C}$ ready for use.

\section{SERA TESTED}

Twenty samples of sera from patients receiving chloramphenicol were collected and stored at $-20^{\circ} \mathrm{C}$ until tested. Each was treated with phosphocellulose powder to remove aminoglycosides ${ }^{10}$ and with paraamino benzoic acid and $\beta$-lactamase (Whatman) to inactivate sulphonamides and penicillins. ${ }^{11}$

CEREBROSPINAL FLUIDS TESTED

Twenty samples of cerebrospinal fluid from neonates 
receiving chloramphenicol for proven or suspected infection were also tested.

\section{Methods of assay}

Nine methods, eight microbiological and one chemical, selected on their applicability to routine clinical microbiological practice were investigated. The principal features of five plate diffusion assay methods are summarised in Table 1. Except where otherwise indicated, all samples and standards were tested in duplicate.

All these plate diffusion assays employed $14 \mathrm{~cm}$ plastic Petri dishes set on levelling trays. The media were pre-dried for 30 minutes at $35^{\circ} \mathrm{C}$, inoculated with indicator organism, and again dried for 30 minutes. Wells were filled to the brim with sample or standard.

Overnight incubation at $35^{\circ} \mathrm{C}$ was required in all cases. Zones of inhibition were read on a magnifying zone reader, and the results were plotted on semilog graph paper. The reproducibility of the methods was determined using an internal standard.

Details of the other methods tested are as follows:

\section{TUBE DIFFUSION METHOD MODIFIED FROM}

THAT OF FUJII et al. ${ }^{16}$

To $50 \mathrm{ml}$ of molten brain heart infusion agar at $50^{\circ} \mathrm{C}$ was added $5 \mathrm{ml}$ defibrinated well aerated sheep blood and $1 \mathrm{ml}$ of a 1:5 dilution of a 24-hour culture of beta-haemolytic streptococci Lancefield group B grown in brain heart infusion broth. Sterile, acidwashed capillary tubes were filled with the molten medium to a depth of approximately $50 \mathrm{~mm}$ by capillary attraction. Standards and samples were added in triplicate to the top of the agar columns to a minimum depth of $5 \mathrm{~mm}$ using a fine capillary pipette. The ends of the tubes were carefully sealed with adhesive tape so as not to displace the agar column, and after 2 hours' prediffusion at $4^{\circ} \mathrm{C}$ they were incubated horizontally at $37^{\circ} \mathrm{C}$ for 18 hours; zones of inhibition of haemolysis were read microscopically using a vernier scale. The results for the standards were plotted on semilog paper from which test results could be read.

TURBIDIMETRIC METHOD USING SHIGELLA SONNEI ${ }^{17}$, OR ESCHERICHIA COLI ${ }^{18}$

$0.5 \mathrm{ml}$ of sample or standard was added to $4.4 \mathrm{ml}$ volumes of brain heart infusion broth together with $0.1 \mathrm{ml}$ Sh. sonnei culture containing $10^{7}$ organisms per $\mathrm{ml}$. Standards and tests were incubated in a waterbath at $37^{\circ} \mathrm{C}$ until the control broth attained an optical density of 0.46 at $575 \mathrm{~nm}$, at which time $0.1 \%$ formaldehyde was added to all tubes. The turbidity of each broth was read on a spectrophotometer, and the results were plotted arithmetically. The method of Joslyn and Galbraith ${ }^{18}$ is essentially similar, but $E$. coli is used as the indicator organism.

CHEMICAL METHOD OF KAKEMI et al. ${ }^{19}$ MODIFIED BY O'GORMAN HUGHES AND DIAMOND 20

Chloramphenicol was extracted with isoamyl acetate at $\mathrm{pH} \mathrm{7 \cdot 0.} \mathrm{The} \mathrm{extract} \mathrm{was} \mathrm{rendered} \mathrm{alkaline} \mathrm{with}$ sodium hydroxide solution and allowed to react with isonicotinic acid hydrazide solution at $30^{\circ} \mathrm{C}$ for 45 minutes, during which time a yellow colour developed proportionate to the amount of chloramphenicol present. The results were read on a spectrophotometer at $430 \mathrm{~nm}$ and the standards plotted as an arithmetic graph from which the results of the test samples could be read.

Table 1 Details of published methods for the assay of chloramphenicol by plate diffusion

\begin{tabular}{|c|c|c|c|c|c|c|}
\hline Method/Ref & Agar & $\operatorname{Vol}(m l)$ & Indicator organism & $\begin{array}{l}\text { Inoculum (surface) } \\
\text { (flooded) }\end{array}$ & Well size $(\mathrm{mm})$ & No. of wells/plate \\
\hline $1 \dagger$ & $\begin{array}{l}\text { Yeast extract agar } \\
5 \mathrm{~g} / 1 \text { (Difco) } \\
\mathrm{pH} 6.2\end{array}$ & 40 & $\begin{array}{l}\text { S. lutea } \\
\text { (NCTC 8340) }\end{array}$ & $\begin{array}{l}1 / 100 \\
\text { overnight culture } \\
\text { (flood) }\end{array}$ & 8 & 14 \\
\hline $2^{12}$ & DST pH $7 \cdot 4$ & 25 & $\begin{array}{l}\text { S. lutea } \\
\text { (NCTC 8340) }\end{array}$ & $\begin{array}{l}1 / 50 \\
\text { overnight culture } \\
\text { (flood) }\end{array}$ & 11 & 14 \\
\hline $3^{13}$ & DST pH $7 \cdot 4$ & $?$ & $\begin{array}{l}\text { E. coli } \\
\text { (NCTC 10418) }\end{array}$ & $?$ & $?$ & $?$ \\
\hline $4^{14}$ & $\begin{array}{l}\text { Anaerobic Agar } \\
\text { (Difco) pH 7.2 }\end{array}$ & 60 & $\begin{array}{l}\text { B. subtilis } \\
\text { spore suspension } \\
\text { (ATCC 6051) }\end{array}$ & $\begin{array}{l}1 / 100 \\
\text { overnight culture } \\
\text { (flood) }\end{array}$ & 8 & 12 \\
\hline $5^{16}$ & $\begin{array}{l}\text { Modified trypticase } \\
\text { soy agar } \\
\text { (BBL)** }\end{array}$ & 18 & C. perfringens & $\begin{array}{l}0.6 \mathrm{ml} \text { log phase } \\
\text { culture } \\
\text { (incorporate) }\end{array}$ & 4 & 14 \\
\hline
\end{tabular}

With the addition of $1.0 \mathrm{ml} 40 \%$ sheep red blood cells and $0.2 \%$ hemin solution $(0.5 \mathrm{mg} / \mathrm{ml})$. 
Results

ASSAY OF CHLORAMPHENICOL STANDARDS Table 2 summarises the results obtained with standard concentrations of chloramphenicol using the nine methods described. In five instances the methods were less sensitive than reported by the authors, and with only three of the methods tested was it possible to detect reliably less than $10 \mathrm{mg} / \mathrm{l}$. The accuracy of the methods varied considerably; the chemical method and all the diffusion methods except that using Clostridium perfringens gave good results with all the results from standard concentrations on or very close to the line of best fit; the results with $C$. perfringens and the turbidimetric methods were less satisfactory, with wide discrepancies between duplicate readings giving a less reliable regression line with a resultant loss in accuracy. A 10 $\mathrm{mg} / \mathrm{l}$ internal standard was included with 10 separate assays using the $S$. lutea/yeast extract diffusion assay and gave a mean reading of $10.07 \mathrm{mg} / \mathrm{l}$ with a range of $9 \cdot 8-10.3 \mathrm{mg} / \mathrm{l}$, showing that the reproducibility of the method is high.

The aliquot required and the time taken for completion of the assay varied considerably. All methods that took less than 18 hours occupied the bench worker for long periods and required constant attention. With the exception of the chemical method, all required daily preparation of cultures and/or assay plates if emergency or out of hours assays were to be performed. Many commercially marketed $14 \mathrm{~cm}$ Petri dishes do not have flat bases, making for difficulties when the agar volumes were small, as for example, in the diffusion assay using $C$. perfringens. Use of $4 \times 4$ inch $(10 \times 10 \mathrm{~cm})$ photographic plates instead of plastic dishes resulted in an improved regression line.

ASSAY OF TEST SAMPLES

On grounds of reproducibility and general applica- bility to routine practice three agar diffusion assays (methods 1, 4, and 5 from Table 1) and the chemical method of Kakemi were selected to assay the test samples. All sera were tested by these methods and the results are shown in Table 3. The $S$. lutea diffusion method detected chloramphenicol at concentrations of $2.5 \mathrm{mg} / \mathrm{l}$. The minimal detectable concentration with the $B$. subtilis diffusion assay was $5 \mathrm{mg} / \mathrm{l}$ and with the chemical method it was $15 \mathrm{mg} / \mathrm{l}$. Thus while the $S$. lutea method yielded measurable chloramphenicol levels in 18 of 20 samples, the $B$. subtilis assay detected chloramphenicol in nine and the chemical method in only six of the serum samples tested (Table 3).

The results obtained using the $C$. perfringens rapid diffusion method are also shown in Table 3 . In this case the low sensitivity of the assay was complicated further by the presence of metronidazole in six of the samples tested. The difficulties experienced in obtaining a satisfactory regression line with this assay, the time taken to set it up, and problems in reading the results accurately do not commend it.

The volume of cerebrospinal fluid available for study in all cases was too small for a comparison of methods to be undertaken, and the samples were tested only by the yeast extract/S. lutea diffusion method. The results obtained were in the range $<2.5-15 \mathrm{mg} / \mathrm{l}$.

\section{Discussion}

Chloramphenicol is widely used, especially in the treatment of infections of the central nervous system, because of the ease with which it crosses the blood brain barrier and the broad spectrum of its antimicrobial activity. However, the risks of haematological and other side effects cannot be ignored. Reliance on recommended dosage regimens is not sufficient to ensure that toxic side effects will not occur, or that therapeutic concentrations, generally

Table 2 Assay methods tested

\begin{tabular}{|c|c|c|c|c|c|}
\hline Method & $\begin{array}{l}\text { Reference to } \\
\text { method }\end{array}$ & $\begin{array}{l}\text { Claimed sensitivity } \\
\text { of assay }(\mathrm{mg} / \mathrm{l})\end{array}$ & $\begin{array}{l}\text { Demonstrated } \\
\text { sensitivity }(\mathrm{mg} / \mathrm{l})\end{array}$ & $\begin{array}{l}\text { Volume of sample* } \\
(\mathrm{ml})\end{array}$ & $\begin{array}{l}\text { Time to result } \\
\text { (hours) }\end{array}$ \\
\hline \multicolumn{6}{|l|}{ Plate diffusion } \\
\hline S. lutea $(0.5 \%$ yeast extract $)$ & - & $2 \cdot 5$ & $2 \cdot 5$ & $0 \cdot 2$ & 18 \\
\hline E. coli & 9 & NS & $10-20$ & $0 \cdot 3$ & 18 \\
\hline S. lutea (DST) & 10 & $2 \cdot 5$ & $5-10$ & $0 \cdot 3$ & 18 \\
\hline B. subtilis & 11 & $2 \cdot 0$ & $5 \cdot 0-7 \cdot 5$ & $0 \cdot 3$ & 18 \\
\hline C. perfringens & 12 & $2 \cdot 0$ & 10 & $0 \cdot 1$ & 6-8 \\
\hline Tube diffusion & 13 & $2 \cdot 0$ & $2 \cdot 5$ & $0 \cdot 1$ & 18 \\
\hline \multicolumn{6}{|l|}{ Tubidimetric } \\
\hline Sh. sonnei & 14 & $1 \cdot 25$ & $5-10$ & $2 \cdot 0$ & 5 \\
\hline E. coli & 15 & NS & $5-10$ & $1 \cdot 0$ & 6 \\
\hline Chemical method & 16 & $10 \cdot 0$ & $15 \cdot 0$ & $1 \cdot 0$ & 4 \\
\hline
\end{tabular}

*Volume required for assay in duplicate.

NS = not stated. 
Table 3 Results of chloramphenicol assay on sera from 20 patients $(\mathrm{mg} / \mathrm{l})$

\begin{tabular}{|c|c|c|c|c|}
\hline \multirow[t]{2}{*}{ Serum number } & \multicolumn{2}{|l|}{ Plate diffusion } & \multirow{2}{*}{$\begin{array}{l}\text { Spectrophotometric } \\
\text { Chemical method } \\
(15 \mathrm{mg} / \mathrm{l})\end{array}$} & \multirow{2}{*}{$\begin{array}{l}\text { Plate diffusion } \\
\text { C. perfringens } \\
(10 \mathrm{mg} / \mathrm{l})\end{array}$} \\
\hline & $\begin{array}{l}\text { S. lutea/yeast extract } \\
(2.5 \mathrm{mg} / \mathrm{l})\end{array}$ & $\begin{array}{l}\text { B. subtilis } \\
(5.0 \mathrm{mg} / \mathrm{l})\end{array}$ & & \\
\hline 1 & 5.0 & $<5.0$ & $<15$ & 10 \\
\hline 2 & $<2.5$ & $<5.0$ & $<15$ & $<10$ \\
\hline 3 & $13 \cdot 5$ & $14 \cdot 0$ & $<15$ & 11 \\
\hline 4 & $5 \cdot 2$ & $<5.0$ & $<15$ & 一* \\
\hline 5 & 5.5 & $<5.0$ & $<15$ & -* \\
\hline 6 & $5 \cdot 3$ & 5.7 & $<15$ & 一* \\
\hline 7 & $5 \cdot 7$ & $5 \cdot 3$ & $<15$ & 6 \\
\hline 8 & $5 \cdot 3$ & $<5.0$ & $<15$ & -* \\
\hline 9 & $5 \cdot 1$ & $<5.0$ & $<15$ & - \\
\hline 10 & $14 \cdot 8$ & $17 \cdot 0$ & 15 & 12 \\
\hline 11 & 5.4 & $<5.0$ & $<15$ & $<10$ \\
\hline 12 & 12.0 & $14 \cdot 0$ & 15 & 10 \\
\hline 13 & 33.0 & $>30.0$ & 34 & $>\mathbf{3 0}$ \\
\hline 14 & 4.8 & $<5.0$ & $<15$ & $<10$ \\
\hline 15 & $19 \cdot 5$ & 20.0 & 27 & NT \\
\hline 16 & 18.5 & $21 \cdot 0$ & 26 & NT \\
\hline 17 & 15.0 & 14.8 & 15 & NT \\
\hline 18 & 5.3 & $5 \cdot 1$ & $<15$ & $<10$ \\
\hline 19 & $5 \cdot 5$ & 7.0 & $<15$ & $<10$ \\
\hline 20 & $<2.5$ & $<5.0$ & $<15$ & - \\
\hline
\end{tabular}

* Samples contained metronidazole and chloramphenicol. NT $=$ not tested.

Minimal detectable levels in parentheses.

taken to be between 10 and $20 \mu \mathrm{g} / \mathrm{ml}$, will be achieved, for there are wide variations in absorption, distribution, metabolism, and elimination in individuals. The age of the recipient is an important factor, ${ }^{6}$ and serum concentrations are particularly variable in the newborn, emphasising the need for regular assay of the drug. ${ }^{7}$ Concomitant phenobarbitone medication may lead to subtherapeutic levels of chloramphenicol after only a few days; 2122 other drugs, such as phenytoin, interact with chloramphenicol, ${ }^{23}$ although the assertion that combined therapy with penicillin increases the renal excretion rate of chloramphenicol ${ }^{5}$ is not proven, since the chloramphenicol assay method used by these authors is affected by metabolites of penicillin. Although combined therapy with these two antimicrobial drugs is not recommended they are often used together. If maximal therapeutic effect is to be achieved without toxic effect, determination of the serum concentration of chloramphenicol is deemed to be mandatory. ${ }^{24}$

The reversible marrow disturbances induced by chloramphenicol are believed to be due to the active component and not to inactive metabolites. 625 Since the ratio of active to inactive compound in serum shows wide variation, especially in neonates ${ }^{6}$ where microsomal enzyme systems are underdeveloped and the glomerular filtration rate may be reduced, it is important that therapy should be monitored using a method which detects only the active component. The assay procedure should not be affected by the presence of other antimicrobia drugs.

Most of the methods that we tested produced $\frac{\partial}{0}$ satisfactory regression lines for reading concentrations up to $50 \mathrm{mg} / \mathrm{l}$. However, their sensitivity varied $\stackrel{\mathrm{\Phi}}{\Omega}$ from 2.5 to $20 \mathrm{mg} / \mathrm{l}$. Toxic side effects of chloram- $\vec{\Rightarrow}$ phenicol therapy are thought to be associated with serum levels above $15-20 \mathrm{mg} / 1^{26} 27$ so that it is important that assay procedures should be as: sensitive as possible, particularly for neonates where dilution of samples may be necessary to obtain? working volumes. In our study, the sensitivity of five of the nine methods tested was less than that reported, greatly reducing the value of the methods. Further, we considered that those methods which failed to produce satisfactory regression lines for the range of? standards tested were unsuitable for use in clinical practice. The turbidimetric assays, which fall intoㅡ. this group, were also unsatisfactory because of then variable effect upon the growth of the indicator organism produced by the large volume of samples required. Most antibiotics which interfere with the N microbiological assay of chloramphenicol can beg selectively removed or inactivated. Metronidazole present in six of the clinical samples that we tested cannot. While this drug has no effect on assay? systems using aerobic organisms its presenced invalidates the rapid diffusion assay using $C \overrightarrow{\vec{D}}$ perfringens.

Physical methods for the assay of chloramphenico using radioactively labelled enzymes, ${ }^{28}$ gas liquice 
chromatography, ${ }^{29}$ and high pressure liquid chromatography ${ }^{30}$ have been described. None of these was used in the present study, but the enzyme methods appear promising as they require only small volumes of serum and are extremely sensitive and specific. However, appropriate acetylating enzymes must be prepared, and a scintillation counter is required. Most chemical and physical methods have a high degree of accuracy and are unaffected by the presence of other antibiotics or other metabolites; an exception is the modified Bratton and Marshall method, ${ }^{31} 32$ which is affected by metabolites of penicillin and sulphonamides. Most chemical methods do not distinguish between active drug and inactive metabolites, and since the components may not be present in fixed proportion in biological samples, their value in clinical microbiology is questionable. We used the modified Kakemi method ${ }^{20}$ because it does not detect esters of chloramphenicol nor the glucuronide or arylamine derivatives. ${ }^{19} \mathrm{High}$ bilirubin values and lipaemic sera are known to interfere with the reaction. ${ }^{33}$ Our investigation suggests that, of nine methods tested, only the diffusion assays using $S$. lutea/yeast extract agar and $B$. subtilis are suitable for routine use, although chloramphenicol cannot be measured at less than $6 \mathrm{mg} / \mathrm{l}$ with the latter method. The assay using $S$. lutea/yeast extract agar is sensitive, easy to perform, and reproducible and uses acceptable volumes of sample. We recommend its use in diagnostic practice.

\section{References}

${ }^{1}$ Leading article. Blood dyscrasias due to chloramphenicol. Br Med J 1952;2:409.

2 Sharp AA. Chloramphenicol induced blood dyscrasias: Analysis of 40 cases. Br Med J 1963;1:735-6.

${ }^{3}$ Annotation. Chloramphenicol toxicity. Lancet 1969; $11: 476$

4 Wade A, Reynolds JEF, eds. Martindale. The Extra Pharmacopoeia. 27th ed. London: The Pharmaceutical Press, 1978;1108.

${ }^{5}$ Windorfer A, Jr, Pringsheim W. Studies on the concentration of chloramphenicol in the serum and cerebrospinal fluid of neonates, infants and small children. Eur J Paed 1977;124:129-38.

${ }^{6}$ Weiss CJ, Glazko AJ, Weston JK. Chloramphenicol in the newborn infant. A physiological explanation of its toxicity when given in excessive doses. $N$ Eng $J$ Med 1960;262:787-94.

7 Davies PA. Antimicrobial therapy in the neonatal period. Br J Hosp Med 1975;14:517-26.

${ }^{8}$ Eichenwald HF, McCracken GH, Jr. Antimicrobial therapy in infants and children. $J$ Ped 1978;93:33777.

${ }^{9}$ Spratt HC. Common bacterial infection in infancy and childhood. 7. Neonatal infections. ADIS Press: Drugs 1978;16:226-37.
${ }^{10}$ Stevens P, Young LS. Simple method for elimination of aminoglycosides from serum to permit bioassay of other antimicrobial agents. Antimicrob Agents Chemother 1977;12:286.

11 Waterworth P. An enzyme preparation inactivating all penicillins and cephalosporins. J Clin Pathol 1973; 26:596-8.

12 Wise R. Chloramphenicol. In: Reeves DS, Phillips I, Williams JD, Wise R, eds. Laboratory Methods in Antimicrobial Chemotherapy. London: Churchill Livingstone, 1978;235-6.

13 Waterworth PM. Laboratory Control. In: Garrod LP, Lambert H, O'Grady F, eds. Antibiotic and Chemotherapy. London: Churchill Livingstone, 1973;490531.

${ }^{14}$ Smith DG, Landers CB, Forgacs J. A cylinder-plate assay for chloromycetin in body fluids and tissue extracts. J Lab Clin Med 1950;36:154-7.

${ }^{15}$ Louie TJ, Tally FP, Bartlett JG, Gorbach SL. Rapid microbiological assay for chloramphenicol and tetracyclines. Antimicrob Agents Chemother 1976;9: 874-8.

${ }^{16}$ Fujii R, Grossman M, Ticknor W. Micromethod for determination of concentration of antibiotics in serum for application in clinical pediatrics. Pediatrics $1961 ; 28: 662-9$.

17 Hans R, Galbraith M, Alegnani WC. Chloramphenicol. In: Kavanagh F, ed. Analytical Microbiology, Volume 1. London: Academic Press, 1963;271-81.

18 Joslyn DA, Galbraith M. A turbidimetric method for the assay of antibiotics. J Bacteriol 1950;59:711-6.

${ }^{19}$ Kakemi K, Arita T, Ohashi S. Determination of chloramphenicol in blood. $J$ Pharmaceut Soc Japan 1962;82:342-5.

${ }^{20}$ O'Gorman Hughes DW, Diamond LK. Chloramphenicol in blood; simple chemical estimations in patients receiving multiple antibiotics. Science 1964; 144:296-7.

${ }^{21}$ Black SB, Levine P, Shinefield HR. The necessity for monitoring chloramphenicol levels when treating neonatal meningitis. J Pediat 1978;92:235-6.

${ }^{22}$ Bloxham RA, Durbin GM, Johnson T, Winterborn MH. Chloramphenicol and phenobarbitone-a drug interaction. Arch Dis Child 1979;54:76-7.

${ }^{23}$ Koup JR, Gibaldi M, McNamara P, Hilligoss DM, Colburn WA, Bruck E. Interaction of chloramphenicol with phenytoin and phenobarbitol. Clin Pharmacol Ther 1978;24:571-5.

24 Yaffe SJ. Antibiotic dosage in newborn and premature infants. JAMA 1965;193:818-20.

${ }^{25}$ McCurdy PR. Plasma concentration of chloramphenicol and bone marrow suppression. Blood 1963; 21:363-72.

${ }^{26}$ Firkin FC. Mitochondrial lesions in reversible erythropoietic depression due to chloramphenicol. J Clin Invest 1972;51:2085-92.

${ }^{27}$ Saidi R, Wallerstein R, Aggeler P. Effect of chloramphenicol on erythropoiesis. J Lab Clin Med 1961 ;57: 247-56.

${ }^{28}$ Leitman PS, White TJ, Shaw WV. Chloramphenicol: An enzymological microassay. Antimicrob Agents Chemother 1976;10:347-53. 
${ }^{29}$ Resnick GL, Corbin D, Sandberg DH. Determination of serum chloramphenicol using gas liquid chromatography and electron capture spectrometry. Anal Chem 1966;38:582-5.

${ }^{30}$ Nilsson-Ehle I, Kahlmeter G, Nilsson-Ehle P. Determination of chloramphenicol in serum and cerebrospinal fluid with high pressure liquid chromatography. Antimicrob Chemother 1978;4:169-76.

${ }^{31}$ Levine J, Fischbach $\mathrm{H}$. The chemical determination of chloramphenicol in biological materials. Antibiot Chemother $1951 ; 1: 59-62$.

${ }^{32}$ Glazko AJ, Wolf LM, Dill WA. Biochemical studies on chloramphenicol (Chloromycetin) 1. Colorimetric methods for determination of chloramphenicol and related nitro compounds. Arch Biochem 1949;23: 411-8.

${ }^{33}$ Daigneault R, Guitard M. An enzyme assay for chloramphenicol with partially purified chloramphenicol acetyltransferase. J Infec Dis 1976;133: 515-22.

Requests for reprints to: $\operatorname{Dr} \mathbf{J}$ de Louvois, Queen Charlotte's Hospital for Women, Goldhawk Road, London W6 0XG, UK. 